\title{
Myths and truths about pediatric psychogenic nonepileptic seizures
}

\author{
Jung Sook Yeom, MD, PhD ${ }^{1,2,3}$, Heather Bernard, LCSW ${ }^{4}$, Sookyong Koh, MD, PhD ${ }^{3,4}$ \\ ${ }^{1}$ Department of Pediatrics, Gyeongsang National University Hospital, ${ }^{2}$ Gyeongsang Institute of Health Science, Gyeongsang National University College of Medicine, \\ Jinju, Korea; ${ }^{3}$ Department of Pediatrics, Emory University School of Medicine, Atlanta, GA, USA; ${ }^{4}$ Department of Pediatrics, Children's Healthcare of Atlanta, Atlanta, \\ GA, USA
}

Psychogenic nonepileptic seizures (PNES) is a neuropsychiatric condition that causes a transient alteration of consciousness and loss of self-control. PNES, which occur in vulnerable individuals who often have experienced trauma and are precipitated by overwhelming circumstances, are a body's expression of a distressed mind, a cry for help. PNES are misunderstood, mistreated, under-recognized, and underdiagnosed. The mindbody dichotomy, an artificial divide between physical and mental health and brain disorders into neurology and psychiatry, contributes to undue delays in the diagnosis and treatment of PNES. One of the major barriers in the effective diagnosis and treatment of PNES is the dissonance caused by different illness perceptions between patients and providers. While patients are bewildered by their experiences of disabling attacks beyond their control or comprehension, providers consider PNES trivial because they are not epileptic seizures and are caused by psychological stress. The belief that patients with PNES are feigning or controlling their symptoms leads to negative attitudes of healthcare providers, which in turn lead to a failure to provide the support and respect that patients with PNES so desperately need and deserve. A biopsychosocial perspective and better understanding of the neurobiology of PNES may help bridge this great divide between brain and behavior and improve our interaction with patients, thereby improving prognosis. Knowledge of dysregulated stress hormones, autonomic nervous system dysfunction, and altered brain connectivity in PNES will better prepare providers to communicate with patients how intangible emotional stressors could cause tangible involuntary movements and altered awareness.

Key words: Neurobiology, Dissociative reaction, Emotional stress, Nonepileptic seizure, Somatic symptoms

\section{Key message}

- Psychogenic non-epileptic seizures (PNES) are events that look like epileptic seizures but are not caused by abnormal electrical discharges.
- PNES are a manifestation of psychological and emotional distress.

- Treatment for PNES does not begin with the psychological intervention but starts with the diagnosis and how the diagnosis is delivered.

- A multifactorial biopsychosocial process and a neurobiological review are both essential components when treating PNES

\section{Introduction}

Psychogenic nonepileptic seizures (PNES) are paroxysmal attacks that may resemble epileptic seizures but are not caused by abnormal brain electrical discharges. At least 15 different labels have been used to describe PNES, including dissociative attacks, hysterical epilepsy, psychogenic seizures, nonepileptic spells, nonphysiologic or functional seizures, and pseudoseizures (a term now widely considered pejorative). ${ }^{1)}$ PNES, the most common functional neurological disorder, falls under the diagnostic category of somatic symptom-related disorder, previously known as conversion disorder or conversion reaction. ${ }^{2)}$ PNES are a manifestation of psychological distress, the body's way of expressing what the mind and mouth cannot. ${ }^{3)}$ PNES are a dissociative response to threatening internal or external stimuli that likely resulted from the interaction of multiple predisposing, precipitating, and perpetuating factors. $\left.{ }^{4}\right)$ One can imagine that the brain becomes overloaded and shuts down in a freeze mode, switching off as if in response to a threatening trigger, so fleeting a response that the patient is unaware.

Providers may feel that PNES is a stress-related mental phenomenon, whereas patients hold markedly different beliefs and views about PNES. ${ }^{5,6)}$ Patients (and their families) feel their seizures could not possibly be related to "stress."7) A history of sexual or physical abuse is a common risk factor for the development of PNES. 2,3) The unique risk factors for pediatric PNES include school difficulties, learning disabilities, or bullying. $\left.{ }^{8}\right)$ However, people with PNES often do not know why they occur

Corresponding author: Sookyong Koh, MD, PhD. Department of Pediatrics, Emory University, Emory Children's Center 364,2015 Uppergate Dr, Atlanta, GA 30322, USA 凶Email: sookyong.koh@emory.edu, https://orcid.org/0000-0002-2717-6888

Received: 15 May, 2020, Revised: 24 July, 2020, Accepted: 12 August, 2020

This is an open-access article distributed under the terms of the Creative Commons Attribution Non-Commercial License (http://creativecommons.org/licenses/bync/4.0/) which permits unrestricted non-commercial use, distribution, and reproduction in any medium, provided the original work is properly cited.

Copyright (c) 2021 by The Korean Pediatric Society 
and remain unaware of their emotional experience, failing to find the link. ${ }^{7)}$ Patients often cannot identify the cause of their emotional or mental stress. ${ }^{2)}$ Thus, there is obvious dissonance and disconnection in the belief and understanding of PNES between patients and treating physicians. ${ }^{6}$ While the symptoms are involuntary, improvement can only occur with the patient's active and very conscious participation. Symptoms of PNES may have transactional value such as avoidance, and this understanding of a subconscious or unconscious drive may allow a point of intervention. Benbadis said it best when he wrote, "PNES are a real condition that arises in response to real stressors. These seizures are not consciously produced and are not the patient's fault." 3,9$)$ PNES and factitious disorder/malingering are completely different disorders: symptoms of the former are not consciously produced and do respond to psychotherapy, whereas those of the latter are consciously produced and do not respond well to psychotherapy. ${ }^{10)}$

PNES are a relatively common condition encountered by pediatricians and neurologists and among the most important differential diagnoses of pediatric epilepsy. This entity constitutes the most common nonepileptic event in school-aged children and adolescents, accounting for $3.5 \%-15 \%$ of pediatric patients referred for video electroencephalography (vEEG). ${ }^{11,12)}$ In adults, about $10 \%$ of outpatients in epilepsy clinics and $30 \%$ of inpatients in epilepsy monitoring units reportedly have PNES. ${ }^{13)}$ The International League Against Epilepsy Commission ranked PNES among the top 3 neuropsychiatric disorders related to epilepsy. ${ }^{14)}$ People with PNES are considered unwelcomed consumers of health care services, such as emergency room visits, brain magnetic resonance imaging (MRI), antiseizure medications, and hospital admissions resulting in an increased health care utilization costs. ${ }^{15)}$ The lifetime dollar cost per year in the PNES patient cohort is $\$ 110-920$ million in the United States alone. ${ }^{15}$ ) Unfortunately, the high medical costs related to the condition fail to translate to improved care and prognosis for patients with PNES. Many patients with PNES quit school or work. ${ }^{16,17)}$ In fact, their health-related quality of life is poorer than patients with epilepsy. ${ }^{18)}$

Pediatric patients with PNES and their families report receiving inadequate treatment and supportive care compared with patients with epilepsy. ${ }^{19)}$ Children with PNES often fall through the cracks between the specialties of neurology and psychiatry, because there is a sense that they are welcome in neither area. ${ }^{5)}$ Neither of these professionals is willing or prepared to assume treating this complex condition. ${ }^{20)}$ Psychiatrists tend to be skeptical of the diagnosis of PNES and question the accuracy of vEEG. ${ }^{10,21)}$ Neurologists are primarily focused on ruling out epilepsy, and many feel that any aspect of the treatment of PNES is not their responsibility. ${ }^{5,10)}$ Because of the gaps in diagnostic and therapeutic services, many patients feel left in limbo. ${ }^{5)}$ In this review, we will discuss challenges of PNES from delivery of diagnosis, the current limited understanding of neurobiology and biopsychosocial aspects, and a hypothesis of the pathophysiology of the condition. We hope that a better understanding of its etiopathology will convince providers that PNES is indeed a brain disorder. Such understanding may lead to better care, treatment, and prognosis for patients with PNES.

How to deliver the diagnosis of PNES: a barrier to communication because of a dualistic conceptualization

The essential step in initiating the treatment of PNES is delivering the confirmed diagnosis in an understanding and nonjudgmental manner. ${ }^{22,23)}$ How the diagnosis is communicated and explained affects the patient's prognosis, in particular, the manner in which the diagnosis is communicated is as important as the specific words that are used, and diagnostic clarity is essential. ${ }^{23)}$ Table 1 summarizes the suggested delivery of the diagnosis. The physician must communicate the diagnosis with conviction and not hesitate or "beat around the bush."23) Psychoeducation can then follow to inform the patients and their families how stress or emotions can affect the body.

In a study investigating who delivered the diagnosis of PNES to patients, over $70 \%$ were neurologists. ${ }^{24)}$ This result is not surprising because neurologists are responsible for caring for patients who present with seizures in many medical centers. If neurologists take the responsibility of diagnosing and explaining PNES, how comfortable and equipped are they to communicate the diagnosis to patients? What is the main barrier? Unfortunately, many neurologists express feelings of discomfort and frustration

Table 1. How to deliver the diagnosis of PNES

\begin{tabular}{|c|c|}
\hline Do & Do not \\
\hline $\begin{array}{l}\text { You have PNES (dissociative attacks). } \\
\text { These events are real and serious. } \\
\text { They are relatively common cause of temporary loss of self-control. }\end{array}$ & $\begin{array}{l}\text { Your events are not "real seizures" } \\
\text { These are just pseudoseizures caused by stress. }\end{array}$ \\
\hline $\begin{array}{l}\text { Do you ever get sad? } \\
\text { How bad does that sadness get? } \\
\text { Do you get anxious? }\end{array}$ & $\begin{array}{l}\text { You need to see a psychiatrist (you have mental illness). "I'm sorry, I can't } \\
\text { help you. This isn't neurological" }\end{array}$ \\
\hline Development of PNES may be linked to trauma (if history known) & Obstinately dig for a trauma history. \\
\hline $\begin{array}{l}\text { Sit down, listen actively. This is what I heard you say } \cdots . \text { Is that correct? } \\
\text { This must have been hard for you. } \\
\text { What have you had to give up? } \\
\text { Avoid eye contact }\end{array}$ & Type into a computer during interview. \\
\hline $\begin{array}{l}\text { Hold hands. } \\
\text { Take deep breaths together. }\end{array}$ & $\begin{array}{l}\text { Sternal rub, deep nailbed pressure. } \\
\text { Antiepileptic drug infusion. }\end{array}$ \\
\hline
\end{tabular}

PNES, psychogenic nonepileptic seizures. 
when presenting the diagnosis of PNES. ${ }^{25)}$ Poor communication of the diagnosis is often the main obstacle to effective treatment. ${ }^{23}$ ) A study exploring interactional resistance between neurologists and PNES patients demonstrated that patients were exceptionally resistant when doctors explained the emotional causes of the problem and recommended psychological treatment. ${ }^{26)} \mathrm{Nu}-$ merous studies reported that most physicians believe that psychological factors are the main or sole etiology of PNES. ${ }^{5,25,27)}$ Some physicians believe that PNES are voluntarily induced. ${ }^{27}$ In contrast, most patients consider themselves mentally healthy and perceive PNES as a biological disorder. ${ }^{6,28)}$ This mismatch in illness perception disrupts physician communication and patient acceptance of the diagnosis. ${ }^{5)}$ If the patient refuses to accept the diagnosis or explanation for their nonepileptic seizures, then there is no basis for psychotherapeutic intervention. ${ }^{5)}$ Despite considerable research delineating the biopsychosocial and neurobiological underpinnings of PNES, many physicians remain uncertain about the plausible biological processes and causes of PNES symptomology. ${ }^{5)}$ Here we introduce a multifactorial biopsychosocial process and review the neurobiological evidence in PNES to bridge the gap in illness perception between physicians and patients.

\section{Multifactorial biopsychosocial model of PNES}

The etiology of PNES is complex. Any single etiology or even contributing factor fails to fully explain the heterogeneous PNES patient population. ${ }^{4)}$ Instead, PNES can be best understood via a biopsychosocial model, ${ }^{4}$ which has been generally applied to functional neurological disorders. ${ }^{29)}$ According to this model, the etiological factors of PNES can be categorized under predisposing, precipitating, and perpetuating factors. ${ }^{4}$ Predisposing factors increase the vulnerability and risk of a child to developing PNES in later life. ${ }^{4)}$ These include biological constitutions, such as genetics, temperament, or neurologic comorbidities and early life traumatic experiences, such as childhood neglect and sexual or physical abuse. ${ }^{4)}$ Precipitating factors refer to a specific event that seems to trigger PNES, which typically occur over days to months before symptom onset. ${ }^{4)}$ Stressful experiences, conflicts, and physical or mental health problems are among the precipitating factors of PNES. Perpetuating factors maintain PNES once it has become established; these include a lack of social support, avoidance, isolation, or a sick role. ${ }^{4)}$ Several of these factors interact with each other and can be identified in most patients with PNES. ${ }^{417)}$ Compared with adults, youth with PNES have a more complex profile of interrelated biopsychosocial risk factors. ${ }^{8,17,30)}$ Extensive literature exists about the neurophysiologic mechanisms of antecedent early life experiences and temperament, 2 of the major predisposing factors of PNES. ${ }^{31,32)}$

\section{Neurobiological aspects of PNES}

This review focuses on the 2 key findings of the neurobiology of PNES: (1) an increased arousal index; and (2) alterations in the cognitive-emotional-executive control circuitry in the brain's connectivity network.

\section{Increased arousal index in patients with PNES}

1) Basal hypercortisolism

The hypothalamic-pituitary-adrenal (HPA) axis is a primary mechanism in the allostatic process through which early life stress contributes to disease. ${ }^{33)}$ Cortisol, a polypeptide hormone that is integral to stress processing, is released from the adrenal cortex in response to adrenocorticotropic hormone, which is released in response to the hypothalamic secretion of corticotropinreleasing hormone. Once the stressors or threatening stimuli are removed, the glucocorticoid level is normalized by negative feedback. Dysregulation of this stress neurocircuitry is the most common feature across stress-related neuropsychiatric diseases such as depression and posttraumatic stress disorder. ${ }^{34)}$

Studies on the relationship of PNES to these neurobiological stress systems have shown dysregulation of the stress hormone homeostasis (Table 2). Tunca et al. ${ }^{35)}$ found decreased cortisol suppression after dexamethasone administration but no differences in basal cortisol levels in blood samples of patients with conversion disorders (including patients with PNES) compared with healthy controls. They interpreted that supervening depressive symptoms in conversion disorder may contribute to disruption of the HPA axis function. Bakvis et al. ${ }^{36}$ reported significantly increased basal diurnal cortisol levels in patients with PNES compared with healthy controls. In contrast to Tunca et al., ${ }^{35,37)}$ Bakvis et al. ${ }^{36}$ ) showed that basal hypercortisolism in patients with PNES was not explained by depression or concurrent seizures but rather by the history of sexual abuse. They suggested that increased HPA axis activity in patients with PNES may not reflect current physical or acute psychological stress but posit a relevant neurobiological marker of its mechanisms. ${ }^{36}$ ) The elevated diurnal cortisol level and decreased sensitivity to dexamethasone suppression are consistent with hypercortisolism in patients with PNES.

How is cortisol involved in the PNES manifestation? Some studies used cortisol as a stress marker and found no difference in prestress basal cortisol levels between patients with PNES and others. ${ }^{38-40)}$ In contrast, basal cortisol level appears to positively correlate with automatic avoidance tendencies, ${ }^{41)}$ threat vigilance, ${ }^{39)}$ and working memory impairments ${ }^{40)}$ to social threat cues or emotional stress in patients with PNES. These findings suggest that stress hormones may be involved in hyperarousal or dysregulation of social-emotional stimuli in PNES.

2) Basal and preictal autonomic arousal in patients with PNES

Autonomic nervous system (ANS) dysfunction has been increasingly recognized to play a role in numerous neuropsychiatric 
disorders, including PNES. However, most research on PNES compared small heterogeneous cohorts of patients with PNES or epilepsy. ${ }^{42)}$ ANS appears to be directly involved in epileptic seizures via centrally mediated sympathetic and parasympathetic system activation by hypersynchronous epileptiform discharges. 43) Thus, ictal tachycardia is a proposed marker for seizure detection. ${ }^{44,45)}$ Moreover, vagal nerve stimulation is a treatment option for drug-resistant epilepsy. In contrast, PNES has heterogeneous psychiatric comorbidities, such as posttraumatic stress syndrome, generalized anxiety disorder, and major depressive disorder, that may have different and variable manifestations of ANS dysfunction. It is not surprising then that, unlike epilepsy, PNES lacks a consistent ANS response. A higher ictal heart rate $(\mathrm{HR})^{44,46-}$ 48) and profound sympathetic activation ${ }^{49-52)}$ during seizures have been reported in patients with epilepsy versus patients with PNES in most studies comparing the autonomic function between them. Only one study reported contradictory results of a higher ictal $\mathrm{HR}^{53)}$ in PNES than in epileptic seizures (Table 3).

Table 2. Hypothalamic-pituitary-adrena axis studies in psychogenic nonepileptic seizures

\begin{tabular}{|c|c|c|c|c|c|c|c|}
\hline Study & Measurements & No. & PNES & ES & $\mathrm{HC}$ & Sampling timing & Findings based on HPA axis \\
\hline $\begin{array}{l}\text { Tunca } \\
\text { et al. }^{35)} \\
(1996)\end{array}$ & Plasma cortisol & 33 & $\begin{array}{l}20 \text { of } 25 \\
\text { patients with } \\
\text { conversion } \\
\text { disorder }\end{array}$ & 0 & 8 & $\begin{array}{l}\text { Baseline: } 8 \text { AM; post DST: next } 8 \\
\text { AM and } 4 \text { PM }\end{array}$ & $\begin{array}{l}\text { Baseline conversion disorders (mainly PNES) = HC; } \\
\text { decreased dexamethasone suppression in } \\
\text { conversion disorders }\end{array}$ \\
\hline $\begin{array}{l}\text { Tunca } \\
\text { et al. }^{37)} \\
(2000)\end{array}$ & Serum cortisol & 26 & 18 & 0 & 8 & $\begin{array}{l}\text { PNES patients: during seizures } \\
(n=18) \text { and next day } 8 \text { AM as } \\
\text { baseline }(n=8) ; H C: 8 \text { AM as } \\
\text { baseline }\end{array}$ & $\begin{array}{l}\text { Baseline PNES = HC; during seizures in afternoon } \\
\text { and evening > baseline } \mathrm{HC}\end{array}$ \\
\hline $\begin{array}{l}\text { Zhang } \\
\text { and Liu } \\
\text { (2008) }\end{array}$ & $\begin{array}{l}\text { ACTH and } \\
\text { cortisol }\end{array}$ & 47 & 11 & 36 & 0 & $\begin{array}{l}\text { Baseline: } 8 \text { AM (awake), } 12 \text { AM } \\
\text { (sleep); peri-ictal: before, } \\
\text { during, after nocturnal eizures }\end{array}$ & $\begin{array}{l}\text { Baseline ACTH and cortisol PNES=ES; ES patients: } \\
\text { significant peri-ictal changes of ACTH and } \\
\text { cortisol; PNES patients: a level similar to that of } \\
\text { awake is maintained during peri-ictal periods }\end{array}$ \\
\hline $\begin{array}{l}\text { Bakvis } \\
\text { et al. }^{38)} \\
(2009)\end{array}$ & $\begin{array}{l}\text { Cortisol (saliva) } \\
\text { and HRV }\end{array}$ & 56 & 19 & 17 & 20 & $\begin{array}{l}\text { Eleven assessment points over a } \\
200 \text { min: rest, stress, and } \\
\text { recovery with reference to the } \\
\text { start of stressor }\end{array}$ & $\begin{array}{l}\text { Group differences were present in only in HRV } \\
\text { (baseline and recovery phase), not in cortisol }\end{array}$ \\
\hline $\begin{array}{l}\text { Bakvis } \\
\text { et al. }^{39)} \\
(2009)\end{array}$ & Cortisol (saliva) & 56 & 19 & 17 & 20 & $\begin{array}{l}\text { Baseline cortisol: } 40 \text { min before } \\
\text { attention bias task (angry face) }\end{array}$ & $\begin{array}{l}\text { Baseline cortisol PNES = HC; positive correlation } \\
\text { between basal cortisol levels and attention bias } \\
\text { scores for threat stimuli only in PNES group } \\
(r=0.49, P=0.035)\end{array}$ \\
\hline $\begin{array}{l}\text { Bakvis } \\
\text { et al. }^{36)} \\
(2010)\end{array}$ & Cortisol (saliva) & 37 & 18 & 0 & 19 & $\begin{array}{l}\text { Awakening cortisol: } 0,15,30,45 \\
60 \text { min; basal diurnal: every } 2 \\
\text { hours from } 10 \text { AM to } 22 \text { PM; } \\
\text { post DST }\end{array}$ & $\begin{array}{l}\text { Basal diurnal cortisol: PNES > HC (with statistically } \\
\text { significance); awakening cortisol and post DST: } \\
\text { PNES = HC }\end{array}$ \\
\hline $\begin{array}{l}\text { Bakvis } \\
\text { et al. }^{40)} \\
(2010)\end{array}$ & Cortisol (saliva) & 39 & 19 & & 20 & $\begin{array}{l}\text { Nine assessment points over a } \\
\text { 145-min period, divided in a } \\
\text { rest, stress and a recovery } \\
\text { phase }\end{array}$ & $\begin{array}{l}\text { PNES=HS throughout time points; high cortisol } \\
\text { stress responses correlated with larger stress- } \\
\text { induced working memory impairments in the no- } \\
\text { distracter condition in PNES patients }\end{array}$ \\
\hline $\begin{array}{l}\text { Bakvis } \\
\text { et al. }^{41)} \\
(2011)\end{array}$ & Cortisol (saliva) & & 12 & & 20 & $\begin{array}{l}\text { Nine assessment points over a } \\
\text { 145-min period, divided in a } \\
\text { rest, stress and a recovery } \\
\text { phase }\end{array}$ & $\begin{array}{l}\text { PNES > HC throughout time points; Increased } \\
\text { social threat avoidance behavior at baseline in } \\
\text { PNES patients, which was correlated with basal } \\
\text { pretask cortisol }\end{array}$ \\
\hline $\begin{array}{l}\text { Novakova } \\
\text { et al. }^{70)} \\
(2017)\end{array}$ & $\begin{array}{l}\text { Cortisol (saliva) } \\
\text { and HRV }\end{array}$ & 44 & 22 & 22 & & $\begin{array}{l}\text { Morning (9 AM) and evening (10 } \\
\text { PM) }\end{array}$ & $\begin{array}{l}\text { PNES=ES diurnal cortisol and HRV changes were } \\
\text { similar between the groups; no close relationship } \\
\text { was found between self-reported stress and } \\
\text { physiologic stress markers (cortisol and HRV) }\end{array}$ \\
\hline
\end{tabular}

HPA, hypothalamic-pituitary-adrenal; HRV, heart rate variability PNES, psychogenic nonepileptic seizures; HC, healthy control; DST, dexamethasone suppression test; ACTH, adrenocorticotropic hormone; ES, epileptic seizures.

Table 3. Autonomic function studies of psychogenic nonepileptic seizures

\begin{tabular}{|c|c|c|c|c|c|c|c|}
\hline Study & Measurements & No. & PNES & ES & $\mathrm{HC}$ & Data acquisition & Findings based on autonomic functions \\
\hline $\begin{array}{l}\text { Opherk and } \\
\text { Hirsch }^{44)} \\
(2002)\end{array}$ & $\mathrm{HR}$ & 105 & 38 & 67 & 0 & $\begin{array}{l}\text { Baseline, ictal onset (first } 10 \mathrm{sec} \\
\text { prior to ictus), ictal (maximal HR } \\
\text { during ictus), and postictal (first } \\
1-2 \text { min postictally) }\end{array}$ & $\begin{array}{l}\text { Baseline HR: PNES }>\text { ES }(P<0.01) \\
\text { Relative HR (\% of baseline HR): nonconvulsive ES > } \\
\text { nonconvulsive PNES in all time points with } \\
P<0.01 \text { (ictal onset, ictal, and postictal) }\end{array}$ \\
\hline $\begin{array}{l}\text { Oliveira } \\
\text { et al. }^{46)} \\
(2007)\end{array}$ & $\mathrm{HR}$ & 59 & 20 & 39 & & $\begin{array}{l}\text { Baseline (from -50 to }-40 \mathrm{~min} \text { ), } \\
\text { preictal (from }-40 \text { to } 0.5 \mathrm{~min} \text { ), } \\
\text { ictal (one } 10 \mathrm{sec} \text { epoch every } 30 \\
\text { sec), and postictal (from }+10 \text { to } \\
+60 \mathrm{~min} \text { ) }\end{array}$ & $\begin{array}{l}\text { Baseline HR CPS }>\text { SPS and PNES }(P<0.05) \\
\text { Ictal HR }>\text { baseline HR in SPS }(P<0.05) \\
\text { Ictal and postictal HR were not changed in CPS and } \\
\text { PNES }\end{array}$ \\
\hline
\end{tabular}


Table 3. Continued

\begin{tabular}{|c|c|c|c|c|c|c|c|}
\hline Study & Measurements & No. & PNES & ES & $\mathrm{HC}$ & Data acquisition & Findings based on autonomic functions \\
\hline $\begin{array}{l}\text { Oliveira } \\
\text { et al. }^{47)} \\
\text { (2009) }\end{array}$ & HR & 143 & 50 & 93 & 0 & Same with Oliveira et al. ${ }^{47)}$ & $\begin{array}{l}\text { Ictal HR increased in mild to severe ES, and severe } \\
\text { PNES than their baseline }(P<0.05) \\
\text { Baseline HR aura }(\mathrm{ES})>\text { other groups of ES and all } \\
\text { of PNES }\end{array}$ \\
\hline $\begin{array}{l}\text { Reinsberger } \\
\text { et al. }{ }^{5)} \\
(2012)\end{array}$ & $H R$ & 88 & 42 & 46 & 0 & $\begin{array}{l}\text { Baseline (at the beginning of the } \\
\text { recording), preictal ( } 30 \mathrm{sec} \\
\text { prior to seizure onset), ictal } \\
\text { (maximal frequency during the } \\
\text { seizure), postictal (60 sec after } \\
\text { the seizure) }\end{array}$ & $\begin{array}{l}\text { Baseline HR PNES }=\text { CPS }(P=0.46) \\
\text { HR (in } \% \text { from baseline): PNES }>\text { CPS in preictal } \\
(P<0.01) \text {, PNES }=\text { CPS in ictal, PNES }<\text { CPS in } \\
\text { postictal }(P<0.05)\end{array}$ \\
\hline $\begin{array}{l}\text { Bakvis } \\
\text { et al. }^{38)} \\
(2009)\end{array}$ & $\begin{array}{l}\text { HRV (as one of } \\
\text { physiologic } \\
\text { markers of } \\
\text { stress) }\end{array}$ & 30 & 19 & & 20 & $\begin{array}{l}-60,-40,-20,0, \text { (rest) }+20,+40 \\
\text { (stress) }+60,+80,+100,+120 \\
\text { and }+140 \text { (recovery) min with } \\
\text { reference to the start of the } \\
\text { stressor }\end{array}$ & $\begin{array}{l}\text { HRV PNES }<\text { HC throughout the experiments } \\
\text { (baseline and recovery phase from stress, } P< \\
0.05 \text { ) }\end{array}$ \\
\hline $\begin{array}{l}\text { Mungen } \\
\text { et al. }^{49)} \\
(2010)\end{array}$ & $\begin{array}{l}\text { DB-RRIV (for para- } \\
\text { sympathetic) and } \\
\text { SSR (for sym- } \\
\text { pathetic) }\end{array}$ & 75 & 25 & 30 & 20 & $\begin{array}{l}\text { Interictal: at least one week or } \\
\text { longer since the last seizure }\end{array}$ & $\begin{array}{l}\text { DB-RRIV interictal and postictal ES }>\mathrm{HC}(P<0.05) \text {, } \\
\text { ES }>\text { PNES }(P<0.05) \text {, and HC }=\text { PNES } \\
\text { SSR interictal and postictal ES }>\text { HS }(P<0.05), \text { ES }> \\
\text { PNES }(P<0.05) \\
\text { PNES patients had normal autonomic functions }\end{array}$ \\
\hline $\begin{array}{l}\text { Ponnusamy } \\
\text { et al. }{ }^{54)} \\
(2011)\end{array}$ & HRV & 129 & 52 & 42 & 35 & $\begin{array}{l}\text { Postictal period: } 2 \text { hr after } \\
\text { seizures }\end{array}$ & $\begin{array}{l}\text { HRV HC }>\text { PNES and ES (all measures } P<0.03 \text { ) } \\
\text { HRV PNES = ES } \\
\text { PNES patients have a lower resting vagal tone and } \\
\text { higher sympathetic tone than healthy controls. }\end{array}$ \\
\hline $\begin{array}{l}\text { Ponnusamy } \\
\text { et al. }{ }^{50)} \\
(2012)\end{array}$ & HRV & 50 & 24 & 26 & 0 & A 3 minute, resting supine ECG & $\begin{array}{l}\text { ES had higher ictal HRV changes than those of } \\
\text { PNES: high sympathetic and reduced vagal tone } \\
\text { during epileptic seizures }\end{array}$ \\
\hline $\begin{array}{l}\text { Reinsberger } \\
\text { et al. }{ }^{51)} \\
(2015)\end{array}$ & EDA & 20 & 9 & 11 & 0 & $\begin{array}{l}\text { Ictal HRV: at least } 1 \text { min of } \\
\text { artifact-free ictal ECG } \\
\text { Interictal HRV: } 3 \text { min of artifact- } \\
\text { free resting ECG }\end{array}$ & $\begin{array}{l}\text { GTCS are associated with a more profound sym- } \\
\text { pathetic arousal than PNES (EDR ES >PNES, } \\
P=0.0074 \text { ) }\end{array}$ \\
\hline 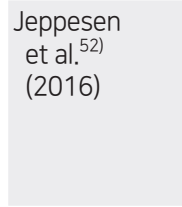 & HRV & $\begin{array}{c}24 \\
(73)^{a)}\end{array}$ & $\begin{array}{c}7 \\
(24)^{\text {a) }}\end{array}$ & $\begin{array}{c}17 \\
(49)^{\mathrm{a}}\end{array}$ & 0 & $\begin{array}{l}\text { A moving window model that } \\
\text { analyzes the previous } 100 \mathrm{R}-\mathrm{R} \\
\text { intervals for each new R-peak } \\
\text { during the immediate preictal, } \\
\text { ictal, and immediate postictal } \\
\text { period of each seizure }\end{array}$ & $\begin{array}{l}\text { Maximum ictal sympathetic index for ES was } \\
\text { higher than PNES (ictal ES >PNES, } P=0.015 \text {; } \\
\text { interictal ES=PNES); minimum parasympathetic } \\
\text { indexes were not different between ES and PNES } \\
\text { (both ictal and interictal) }\end{array}$ \\
\hline $\begin{array}{l}\text { van der Kruijs } \\
\text { et al. }{ }^{71)} \\
(2016)\end{array}$ & HRV & $\begin{array}{c}20 \\
(118)^{\mathrm{a})}\end{array}$ & $\begin{array}{c}20 \\
(118)^{a)}\end{array}$ & & & $\begin{array}{l}12 \text { Intervals (of } 5 \text { min each) pre- } \\
\text { ceded and followed episodes, } \\
\text { and } 2 \text { intervals during episodes }\end{array}$ & $\begin{array}{l}\text { PNES episodes are preceded by increased sym- } \\
\text { pathetic functioning, which is followed by an } \\
\text { increase in parasympathetic functioning during } \\
\text { and after PNES }\end{array}$ \\
\hline $\begin{array}{l}\text { Novakova } \\
\text { et al. }^{70)} \\
(2017)\end{array}$ & $\begin{array}{l}\text { Cortisol (saliva) } \\
\text { and HRV }\end{array}$ & 44 & 22 & 22 & & $\begin{array}{l}\text { Morning (9 AM) and evening } \\
\text { (10PM) }\end{array}$ & $\begin{array}{l}\text { PNES=ES diurnal cortisol and HRV changes were } \\
\text { similar between the groups; no close relationship } \\
\text { was found between self-reported stress and } \\
\text { physiologic stress markers (cortisol and HRV) }\end{array}$ \\
\hline $\begin{array}{l}\text { Indranada } \\
\text { et al. }{ }^{57)} \\
(2019)\end{array}$ & $\mathrm{HR}$ and $\mathrm{RR}$ & 146 & 101 & 45 & & $\begin{array}{l}\text { At baseline, } 5 \text { min, } 4 \text { min, } 3 \text { min, } \\
2 \text { min, } 1 \text { min, before the seizure } \\
\text { event, and immediately prior to } \\
\text { onset }\end{array}$ & $\begin{array}{l}\text { Baseline HR and RR PNES = ES } \\
\text { Increasing autonomic arousal prior to seizure } \\
\text { events in PNES (rising HR and RR from baseline } \\
\text { to the onset of their seizures, } P<0.001 \text { and } \\
P=0.012 \text {, respectively), but not in ES }\end{array}$ \\
\hline $\begin{array}{l}\text { Zsom et al. }{ }^{53)} \\
(2019)\end{array}$ & $\begin{array}{l}\text { EDA, HR, BVP, and } \\
\text { BT via wearable- } \\
\text { sensors }\end{array}$ & $\begin{array}{c}18 \\
(35)^{\mathrm{a})}\end{array}$ & $\begin{array}{c}8 \\
(12)^{a)}\end{array}$ & $\begin{array}{c}10 \\
(23)^{\mathrm{a})}\end{array}$ & & $\begin{array}{l}\text { 1-min segments with no tem- } \\
\text { poral overlap: } 104 \text { interictal } \\
\text { data points vs. } 276 \text { ictal data } \\
\text { points }\end{array}$ & $\begin{array}{l}\text { A higher ictal HR }\left(P=3 \times 10^{-82}\right) \text { and EDA }\left(P=2 \times 10^{-32}\right) \\
\text { compare to baseline in PNES, but those are } \\
\text { similar in patients with ES; patients with PNES had } \\
\text { a higher ictal HR and EDA than patients with ES }\end{array}$ \\
\hline $\begin{array}{c}\text { Badry }^{48)} \\
(2020)\end{array}$ & $\begin{array}{l}\mathrm{SaO}_{2}, \mathrm{HR}, \mathrm{RR}, \mathrm{BT} \\
\mathrm{SBP} \text {, and DBP }\end{array}$ & 94 & 49 & 45 & & $\begin{array}{l}\text { At baseline (a single point } \\
\text { measurement during relax) and } \\
\text { maximal values during the } \\
\text { attacks }\end{array}$ & $\begin{array}{l}\text { Baseline vital signs PNES }=\text { ES } \\
\text { Ictal HR ES }>\text { PNES }(P=0.003), \mathrm{SaO}_{2} \text { ES }<\text { PNES } \\
(P=0.04) \\
\text { Ictal RR }(P=0.02) \text { and SBP ES }<\text { PNES }(P=0.04)\end{array}$ \\
\hline
\end{tabular}

PNES, psychogenic nonepileptic seizures; HR, heart rate; ES, epileptic seizures; CPS, complex partial seizures; SPS, simple partial seizures; ECG, electrocardiogram; EDA, electrodermal activity; GTCS, generalized tonic-clonic seizures; BVP, blood volume pulse; BT, body temperature; CSI, cardiac vagal index; DB-RRIV, deep breath RR intervals; DBP, diastolic blood pressure; HC, healthy control; HRV, heart rate variability; RR, respiratory rate; SaO2, oxygen saturation; SBP, systolic blood pressure; SSR, sympathetic skin response.

a) Event number. 
Studies focusing on ANS function at rest (interictal period) or its preictal changes of PNES have been more revealing. HR variability (HRV) was low in patients with PNES at rest versus normal controls. ${ }^{54)} \mathrm{A}$ significant reduction in HRV occurred at baseline and after recovery from acute social stress induction in patients with PNES versus normal controls. ${ }^{38)} \mathrm{HRV}$ is widely used as a standard index for assessing ANS functions, because a lower HRV is a reliable indicator of reduced parasympathetic activity. The parasympathetic system is a "buffer" that allows individuals to react properly to external stimuli. In addition, decreased HRV is related to increased arousal and anxiety ${ }^{55}$ and reduced ability to cope with internal and external stressors. ${ }^{56}$ Therefore, sustained baseline vulnerability, such as hyperarousal or low vagal tone at rest, may underlie the pathophysiology of PNES ${ }^{38,51)}$ An acute temporal sequence analysis of preictal HR showed a significantly rising HR from baseline toward seizure onset in patients with PNES but not in patients with epilepsy. ${ }^{57)}$ A study comparing preictal, ictal, and postictal HR differences in patients with PNES and epileptic controls identified significant preictal HR increases in the former. ${ }^{58)}$ Together with previous studies, these findings suggest that PNES events are likely to occur when autonomic arousal surges in the absence of adequate buffering from the parasympathetic nervous system.

\section{Connectivity changes in brain networks in PNES}

Alterations in the intrinsic connectivity of the brain in patients with PNES have been explored using functional MRI (fMRI), which analyzes fluctuations in the blood oxygenation leveldependent (BOLD) signal, which is indirectly correlated with neuronal activity. Resting-state fMRI (rsfMRI) measures synchronous activations of the BOLD signal between brain regions to investigate the functional intrinsic connectivity of the brain. ${ }^{59)}$ In contrast, task- or event-related fMRI infers certain areas of the brain in which activation occurs during the performance of a task or in response to a stimulus. ${ }^{59)}$ We chose to review selected welldesigned case-controlled fMRI studies below (Table 4).

\section{1) Lost optimal network topology in patients with PNES}

Ding et al. ${ }^{60)}$ simultaneously investigated structural and functional connectivity in patients with PNES using rsfMRI and diffusion tensor imaging while searching for a potential imaging biomarker for patients with PNES. They found that patients with PNES had a suboptimal "small-worldness" in their functional and structural connectivity networks compared with normal healthy controls. ${ }^{60)}$ Specifically, large-scale brain networks shift toward a more regular (lattice-like) organization. ${ }^{60)}$ Small-worldness is a fundamental organization principle in the brain network

Table 4. FMRI studies of psychogenic nonepileptic seizures

\begin{tabular}{|c|c|c|c|c|c|c|}
\hline Study & Imaging & No. & PNES & ES & $\mathrm{HC}$ & Findings \\
\hline $\begin{array}{l}\text { van der Kruijs } \\
\text { et al. }{ }^{62)} \\
(2012)\end{array}$ & $\begin{array}{l}\text { rsfMRI, } \\
\text { event- } \\
\text { related fMRI }\end{array}$ & 23 & 11 & 0 & 12 & $\begin{array}{l}\text { PNES increased FC between areas involved in emotion (insula), executive control (inferior frontal } \\
\text { gyrus and parietal cortex) and movement (precentral sulcus) in resting state, which were } \\
\text { significantly associated with dissociation scores.; no significant difference for activation pattern } \\
\text { to fMRI tasks }\end{array}$ \\
\hline $\begin{array}{l}\text { Ding et al. }{ }^{60)} \\
(2013)\end{array}$ & rsfMRI, DTI & 37 & 17 & 0 & 20 & $\begin{array}{l}\text { PNES patients lost optimal topological organization in FC and SC networks; PNES decreased } \\
\text { coupling strength between FC and SC }\end{array}$ \\
\hline $\begin{array}{l}\text { Ding et al. } \\
(2014)\end{array}$ & rsfMRI & 38 & 18 & 0 & 20 & $\begin{array}{l}\text { PNES showed abnormal functional connectivity density regions mainly associated with attention } \\
\text { (frontal cortex), sensorimotor (sensorimotor cortex), and emotion (cingulate gyrus and insular); } \\
\text { FC was disrupted between these regions. }\end{array}$ \\
\hline $\begin{array}{l}\text { van der Kruijs } \\
\text { et al. } \\
(2014)\end{array}$ & rsfMRI & 48 & 21 & 0 & 27 & $\begin{array}{l}\text { PNES increased coactivation of fronto-parietal network (OFC, insular and subcallosal cortex), } \\
\text { executive control network (cingulate and insular cortex), sensorimotor network (cingulate gyrus, } \\
\text { SPL, pre- and postcentral gyri and SMA, and default mode network; The connectivity strength } \\
\text { within these regions significantly correlated with dissociation scores in PNES }\end{array}$ \\
\hline $\begin{array}{l}\text { Li et al. }{ }^{64)} \\
(2014)\end{array}$ & rsfMRI & 38 & 18 & 0 & 20 & $\begin{array}{l}\text { Insular subregions (vAI, dAI, PI) have a significantly higher connectivity within motor (postcentral } \\
\text { gyrus/SMA and putamen), visual memory (lingual gyrus) and sensory process (parietal lobe) } \\
\text { region in PNES; the correlation between the altered FC values and the frequency of PNES } \\
\text { episodes }\end{array}$ \\
\hline $\begin{array}{l}\text { Li et al. }^{72)} \\
(2015)\end{array}$ & rsfMRI & 38 & 18 & 0 & 20 & $\begin{array}{l}\text { PNES exhibited widespread intra-regional neural network deficits, including increasing (DLPFC, } \\
\text { sensorimotor, and limbic system) and decreased (ventrolateral prefrontal cortex) connectivity; } \\
\text { PNES frequency is correlated with connectivity between SMA and anterior cingulate cortex }\end{array}$ \\
\hline $\begin{array}{l}\text { Szaflarski } \\
\text { et al. }{ }^{67)} \\
(2018)\end{array}$ & $\begin{array}{l}\text { rsfMRl, } \\
\text { emotional } \\
\text { face task } \\
\quad \text { fMRI }\end{array}$ & 48 & 12 & $\begin{array}{c}12 \\
(\text { TLE) }\end{array}$ & 24 & $\begin{array}{l}\text { Compared with TLE, PNES exhibited increased fMRI response to happy, neutral, and fearful faces } \\
\text { in visual, temporal, and/or parietal regions and decreased fMRI response to sad faces in the } \\
\text { putamen bilaterally; RSFC of the left and right amygdala to brain regions including emotion } \\
\text { regulation and motor control circuits was increased in PNES }\end{array}$ \\
\hline $\begin{array}{l}\text { Dienstag } \\
\text { et al. } \\
(2019)\end{array}$ & rsfMRI & 22 & 9 & 0 & 13 & $\begin{array}{l}\text { PNES exhibited disturbances of functional disturbances between the MTL and the sensorimotor } \\
\text { cortex and between the MTL and ventral attention networks. }\end{array}$ \\
\hline $\begin{array}{l}\text { Allendorfer } \\
\text { et al. }{ }^{68)} \\
(2019)\end{array}$ & $\begin{array}{l}\text { rsfMRI, } \\
\text { stress task } \\
\quad \text { fMRI }\end{array}$ & 24 & 12 & 0 & 12 & $\begin{array}{l}\text { PNES exhibited hyporeactivity to psychological stress (hypo reactivity in left/right amygdala and } \\
\text { left hippocampus), along with greater emotion-motor-executive control network (increased } \\
\text { connectivity between right amygdala to left precentral and inferior/middle frontal gyri) in RSFC. }\end{array}$ \\
\hline
\end{tabular}

fMRI, functional magnetic resonance imaging; PNES, psychogenic nonepileptic seizures; refMRI, resting-state functional magnetic resonance image; ES, epileptic seizures; HC, healthy control; FC, functional connectivity; DTI, diffusion tensor imaging; SC, structural connectivity; OFC, orbitofrontal cortex; SPL, superior parietal lobe; SMA, supplementary motor area; vAl, ventral anterior insula; dAl, dorsal anterior insula; PI, posterior insula; DLPFC, dorsolateral prefrontal cortex; TLE, temporal lobe epilepsy; RSFC, resting state functional connectivity; MTL, medial temporal lobe. 
that has unique properties of regional specialization with efficient information transfer. ${ }^{61)}$ In contrast, regular networks have a lower potential for global integration with a less efficient information transfer. ${ }^{60)}$ They also found that the coupling of functional-structural connectivity was decreased in PNES. ${ }^{60)}$ Finally, they postulated that patients with PNES have abnormal brain network mechanisms and a less optimal topological organization of functional and structural connectivity. ${ }^{60)}$

\section{2) Altered resting-state cognitive-emotional-executive control network}

Van der Kruijs et al. ${ }^{62)}$ first reported the altered functional connectivity of PNES using rsfMRI. Patients with PNES had a stronger connection between brain regions involving emotion (insula) and the precentral sulcus (motor planning) or the parietal lobe (processing of sensory information) than their normal healthy counterparts. ${ }^{62)} \mathrm{A}$ significant positive correlation was noted between dissociation scores and functional connectivity values of the insular-precentral sulcus. ${ }^{62)}$ These findings suggest that increased connectivity between the brain regions involved in emotional processing and motor planning can bypass the inhibitory control provided by the frontal brain regions and result in involuntary movements. ${ }^{62)} \mathrm{A}$ subsequent study further demonstrated that alterations of the resting-state networks involving frontoparietal activation, executive control, sensorimotor functioning, and the default mode were related to the dissociation occurring in patients with PNES. ${ }^{63)}$

Similar findings were replicated by other researchers. Li et al. ${ }^{64)}$ found that functional connectivity values between brain regions involving motor functions and an insular subregion were positively correlated with PNES attack frequency. Thus, abnormal emotional-motor mechanisms of the brain network may predispose an individual to PNES. ${ }^{64)}$ Ding et al. ${ }^{65)}$ found a correlation between disease duration and hyperactivation of the occipital cortex to visual stimuli in patients with PNES and suggested that such an increased response to external stimuli may reflect an adaptive change in these patients to chronic hypervigilance. Dienstag et al. ${ }^{66)}$ added an interesting aspect of long-term memory involvement in PNES pathogenesis by demonstrating impaired connectivity between the medial temporal lobe (MTL), a brain region involved in autobiographical memory, and the sensorimotor cortex, and between the MTL and the ventral attention network in patients with PNES. ${ }^{66)}$ Their findings support their hypothesis that PNES symptoms result from psychological defense mechanisms used by patients to "block" their awareness of traumatic memories. $\left.{ }^{66}\right)$ Two recent studies assessed the functional connectivity of the amygdala, which has been implicated in emotion processing and the pathology of PNES, to other brain regions. Compared with patients with temporal lobe epilepsy, those with PNES showed an increased resting-state functional connectivity between the amygdala and brain circuits involved in emotional regulation and motor control. ${ }^{67)}$ These results suggest that abnormalities in emotional processing create an increased propensity to seizures precipitated by heightened stress in patients with PNES. ${ }^{67)}$ Allendorfer et al. ${ }^{68)}$ evaluated the psychological stress response in the brain regions involved in emotional-motor-executive control in PNES. Using fMRI, they demonstrated hyporeactivity in the amygdala to psychological stress along with greater emotional-motor-executive control network resting-state functional connectivity in patients with PNES versus healthy controls. ${ }^{68)}$ Allendorfer et al. ${ }^{68)}$ suggested dysregulation of the stress response circuitry involving the emotional-motor-executive control network in PNES. All of these findings are supportive of the previous findings of the emotional processing network of patients with PNES in that emotion drives involuntary motor symptoms by overriding executive control in patients with PNES. Thus, generations of PNES appear to be related to altered attention, sensorimotor, and emotional system connectivity.

\section{3) Task- or event-related fMRI in PNES}

Only 3 studies to date have analyzed task- or event-related fMRI and rsfMRI findings in patients with PNES. Differences in cortical responses to facial emotional processing between patients with PNES and temporal lobe epilepsy were noted; specifically, patients with PNES exhibited increased fMRI responses to happy, neutral, and fearful faces in the visual, temporal, or parietal regions and decreased fMRI responses to sad faces in the bilateral putamen. ${ }^{67}$ Psychological stress responses in the brain regions showed hyporeactivity in the amygdala and left hippocampus in patients with PNES versus healthy controls. ${ }^{68)}$ Van der Kruijs et al. ${ }^{62)}$ found no significant differences in many task-related paradigms (picture coding, emotional stimuli, Stroop color-naming, susceptibility to hypnotic induction related to dissociation) between patients with PNES and normal healthy controls in an overall brain analysis.

\section{Conclusions}

Psychogenic PNES superficially resemble seizures, although unlike epileptic seizures, they are not induced by abnormal electrical activity in the brain. PNES are a physical manifestation of psychological distress, a dissociative state, and a common cause of transient loss of awareness and consciousness. Patients with PNES are often blamed for their symptoms as if they are making them up when, in fact, they are frightened, unaware of their emotional stress, and unable to find the mind-body link. PNES are as costly and disabling as epileptic seizures, although the health-related quality of life of patients with PNES is worse than that of patients with epilepsy. The diagnosis and treatment of PNES are often delayed because of barriers to care. It is important to recognize and communicate to patients that PNES is indeed a brain disorder, life experiences can change the brain to make one vulnerable to PNES, and the condition will improve with intervention. PNES may be considered a normal reaction to an overwhelming experience that exceeds and overloads a person's nervous system and coping ability. Evidence shows that 
patients with PNES have heightened reactions to external or internal stress in the HPA axis and a dysregulated ANS. Functional connectivity is altered in patients with PNES, particularly in brain networks involving the cognitive-emotional-executive control circuitry. These changes may reflect an adaptation to long-term hypervigilance and an increased response to stressful stimuli. The truth about PNES lies beyond the dualistic framework of psychologic versus biologic. Rather, an integrative and inclusive biopsychosocial perspective is more suitable for addressing PNES, a condition that lies at the interface of neurology and psychiatry. One needs to break down the artificial divide between physical health and mental health and recognize the inseparability of the mind and body.

\section{Conflicts of interest}

No potential conflict of interest relevant to this article was reported.

\section{Acknowledgments}

This work was supported by the Gyeongsang National University Fund for Professors on Sabbatical Leave, 2019.

See the commentary "Psychogenic nonepileptic seizures; beyond differentiating from epileptic seizures" via https://doi. org/10.3345/cep.2020.01207.

\section{References}

1. Asadi-Pooya AA, Brigo F, Mildon B, Nicholson TR. Terminology for psychogenic non-epileptic seizures: Making the case for "functional seizures". Epilepsy Behav 2020;104:106895.

2. International League Against Epilepsy. Unraveling the mystery of psychogenic non-epileptic seizures. EPIGRAPH VOL. 21 ISSUE 1, WINTER 2019 [Internet]. Flower Mound (TX): International League Against Epilepsy; c2021 [cited 2020 May 1]. Available from: https://www.ilae. org/journals/epigraph/epigraph-vol-21-issue-1-winter-2019/unravelingthe-mystery-of-psychogenic-non-epileptic-seizures.

3. Epilepsy Foundation. The Truth about Psychogenic Nonepileptic Seizures [Internet]. Landover (MD): Epilepsy Foundation; 2019 [cited 2020 May 1]. Available from: https://www.epilepsy.com/article/2014/3/truth-aboutpsychogenic-nonepileptic-seizures.

4. Reuber M. The etiology of psychogenic non-epileptic seizures: toward a biopsychosocial model. Neurol Clin 2009;27:909-24.

5. Rawlings $\mathrm{GH}$, Reuber M. Health care practitioners' perceptions of psychogenic non-epileptic seizures: a systematic review of qualitative and quantitative studies. Epilepsia 2018;59:1109-23.

6. Whitehead K, Kandler R, Reuber M. Patients' and neurologists' perception of epilepsy and psychogenic non-epileptic seizures. Epilepsia 2013;54: 708-17.

7. Stone J, Binzer M, Sharpe M. Illness beliefs and locus of control: a comparison of patients with pseudoseizures and epilepsy. J Psychosom Res 2004;57:541-7.

8. Plioplys S, Doss J, Siddarth P, Bursch B, Falcone T, Forgey M, et al. A multisite controlled study of risk factors in pediatric psychogenic non-epileptic seizures. Epilepsia 2014;55:1739-47.

9. Benbadis SR, Friedman AL, Kosalko J, Stagno SJ. Psychogenic seizures: a guide for patients and families. J Neurosci Nurs 1994;26:306-8.

10. Tolchin B, Martino S, Hirsch LJ. Treatment of patients with psychogenic nonepileptic attacks. JAMA 2019;321:1967-8.
11. Patel H, Scott E, Dunn D, Garg B. Nonepileptic seizures in children. Epilepsia 2007;48:2086-92.

12. Kotagal P, Costa M, Wyllie E, Wolgamuth B. Paroxysmal non-epileptic events in children and adolescents. Pediatrics 2002;110:e46.

13. Martin R, Burneo JG, Prasad A, Powell T, Faught E, Knowlton R, et al. Frequency of epilepsy in patients with psychogenic seizures monitored by video-EEG. Neurology 2003;61:1791-2.

14. Kerr MP, Mensah S, Besag F, de Toffol B, Ettinger A, Kanemoto K, et al. International consensus clinical practice statements for the treatment of neuropsychiatric conditions associated with epilepsy. Epilepsia 2011;52: 2133-8.

15. Martin RC, Gilliam FG, Kilgore M, Faught E, Kuzniecky R. Improved health care resource utilization following video-EEG-confirmed diagnosis of non-epileptic psychogenic seizures. Seizure 1998;7:385-90.

16. Benbadis SR, Chichkova R. Psychogenic pseudosyncope: an underestimated and provable diagnosis. Epilepsy Behav 2006;9:106-10.

17. Doss JL, Plioplys S. Pediatric psychogenic non-epileptic seizures: a concise review. Child Adolesc Psychiatr Clin N Am 2018;27:53-61.

18. Szaflarski JP, Hughes C, Szaflarski M, Ficker DM, Cahill WT, Li M, et al. Quality of life in psychogenic non-epileptic seizures. Epilepsia 2003;44: 236-42.

19. McWilliams A, Reilly C, McFarlaneFA, Booker E, Heyman I. Nonepileptic seizures in the pediatric population: A qualitative study of patient and family experiences. Epilepsy Behav 2016;59:128-36.

20. Smith BJ. Closing the major gap in PNES research: finding a home for a borderland disorder. Epilepsy Curr 2014;14:63-7.

21. Harden CL, Burgut FT, Kanner AM. The diagnostic significance of videoEEG monitoring findings on pseudoseizure patients differs between neurologists and psychiatrists. Epilepsia 2003;44:453-56.

22. Mayor R, Brown RJ, Cock H, House A, Howlett S, Singhal S, et al. Shortterm outcome of psychogenic non-epileptic seizures after communication of the diagnosis. Epilepsy Behav 2012;25:676-81.

23. Benbadis SR. Psychogenic non-epileptic attacks. In: Wyllie E, editor. Wyllie's treatment of epilepsy: principles and practice. 5th ed. Philadelphia (PA): Lippincott Williams \& Wilkins, 2012:486-4.

24. Dworetzky BA. What are we communicating when we present the diagnosis of PNES? Epilepsy Curr 2015;15:353-7.

25. Shneker BF, Elliott JO. Primary care and emergency physician attitudes and beliefs related to patients with psychogenic non-epileptic spells. Epilepsy Behav 2008;13:243-7.

26. Monzoni CM, Duncan R, Grunewald R, Reuber M. Are there interactional reasons why doctors may find it hard to tell patients that their physical symptoms may have emotional causes? A conversation analytic study in neurology outpatients. Patient Educ Couns 2011;85:e189-200.

27. Nielsen ES, Wichaidit BT, Ostergaard JR, Rask CU. Paediatricians' attitudes to and management of functional seizures in children. Eur J Paediatr Neurol 2018;22:774-81.

28. Karterud HN, Risor MB, Haavet OR. The impact of conveying the diagnosis when using a biopsychosocial approach: a qualitative study among adolescents and young adults with NES (non-epileptic seizures). Seizure 2015;24:107-13.

29. Voon V, Cavanna AE, Coburn K, Sampson S, Reeve A, LaFrance WC Jr, et al. Functional neuroanatomy and neurophysiology of functional neurological disorders (conversion disorder). J Neuropsychiatry Clin Neurosci 2016;28:168-90.

30. Dworetzky BA. Psychogenic non-epileptic seizures: children are not miniature adults. Epilepsy Curr 2015;15:174-6

31. Agorastos A, Pervanidou P, Chrousos GP, Baker DG. Developmental trajectories of early life stress and trauma: A narrative review on neurobiological aspects beyond stress system dysregulation. Front Psychiatry 2019; 10:118.

32. Whittle S, Allen NB, Lubman DI, Yucel M. The neurobiological basis of temperament: towards a better understanding of psychopathology. Neurosci Biobehav Rev 2006;30:511-25.

33. Essex MJ, Shirtcliff EA, Burk LR, Ruttle PL, Klein MH, Slattery MJ, et al. Influence of early life stress on later hypothalamic-pituitary-adrenal axis functioning and its covariation with mental health symptoms: a study of 
the allostatic process from childhood into adolescence. Dev Psychopathol 2011;23:1039-58.

34. Bale TL, Epperson CN. Sex differences and stress across the lifespan. Nat Neurosci 2015;18:1413-20.

35. Tunca Z, Fidaner H, Cimilli C, Kaya N, Biber B, Yesil S, et al. Is conversion disorder biologically related with depression? A DST study. Biol Psychiatry 1996;39:216-9.

36. Bakvis P, Spinhoven P, Giltay EJ, Kuyk J, Edelbroek PM, Zitman FG, et al. Basal hypercortisolism and trauma in patients with psychogenic nonepileptic seizures. Epilepsia 2010;51:752-9.

37. Tunca Z, Ergene U, Fidaner H, Cimilli C, Ozerdem A, Alkin T, et al. Reevaluation of serum cortisol in conversion disorder with seizure (pseudoseizure). Psychosomatics 2000;41:152-3.

38. Bakvis P, Roelofs K, Kuyk J, Edelbroek PM, Swinkels WA, Spinhoven P. Trauma, stress, and preconscious threat processing in patients with psychogenic nonepileptic seizures. Epilepsia 2009;50:1001-11.

39. Bakvis P, Spinhoven P, Roelofs K. Basal cortisol is positively correlated to threat vigilance in patients with psychogenic nonepileptic seizures. Epilepsy Behav 2009;16:558-60.

40. Bakvis P, Spinhoven P, Putman P, Zitman FG, Roelofs K. The effect of stress induction on working memory in patients with psychogenic nonepileptic seizures. Epilepsy Behav 2010;19:448-54.

41. Bakvis P, Spinhoven P, Zitman FG, Roelofs K. Automatic avoidance tendencies in patients with psychogenic non-epileptic seizures. Seizure 2011; 20:628-34.

42. Wiseman H, Reuber M. New insights into psychogenic non-epileptic seizures 2011-2014. Seizure 2015;29:69-80.

43. Osorio I. Automated seizure detection using EKG. Int J Neural Syst 2014; 24:1450001.

44. Opherk C, Hirsch LJ. Ictal heart rate differentiates epileptic from nonepileptic seizures. Neurology 2002;58:636-8.

45. Eggleston KS, Olin BD, Fisher RS. Ictal tachycardia: the head-heart connection. Seizure 2014;23:496-505.

46. Oliveira GR, Gondim Fde A, Hogan RE, Rola FH. Heart rate analysis differentiates dialeptic complex partial temporal lobe seizures from auras and non-epileptic seizures. Arq Neuropsiquiatr 2007;65:565-8.

47. Oliveira GR, Gondim Fde A, Hogan ER, Rola FH. Movement-induced heart rate changes in epileptic and non-epileptic seizures. Arq Neuropsiquiatr 2009;67:789-91.

48. Badry R. Changes in Vital signs during epileptic and psychogenic nonepileptic attacks: a video-eeg study. J Clin Neurophysiol 2020;37:74-8.

49. Mungen B, Berilgen MS, Arikanoglu A. Autonomic nervous system functions in interictal and postictal periods of non-epileptic psychogenic seizures and its comparison with epileptic seizures. Seizure 2010;19:26973.

50. Ponnusamy A, Marques JL, Reuber M. Comparison of heart rate variability parameters during complex partial seizures and psychogenic non-epileptic seizures. Epilepsia 2012;53:1314-21.

51. Reinsberger C, Sarkis R, Papadelis C, Doshi C, Perez DL, Baslet G, et al. Autonomic changes in psychogenic nonepileptic seizures: toward a potential diagnostic biomarker? Clin EEG Neurosci 2015;46:16-25.

52. Jeppesen J, Beniczky S, Johansen P, Sidenius P, Fuglsang-Frederiksen A. Comparing maximum autonomic activity of psychogenic non-epileptic seizures and epileptic seizures using heart rate variability. Seizure 2016;37: 13-9.

53. Zsom A, Tsekhan S, Hamid T, Levin J, Truccolo W, LaFrance WC, et al. Ictal autonomic activity recorded via wearable-sensors plus machine learning can discriminate epileptic and psychogenic non-epileptic seizures. Conf Proc IEEE Eng Med Biol Soc 2019;2019:3502-6.

54. Ponnusamy A, Marques JL, Reuber M. Heart rate variability measures as biomarkers in patients with psychogenic nonepileptic seizures: potential and limitations. Epilepsy Behav 2011;22:685-91.

55. Thayer JF, Friedman BH, Borkovec TD. Autonomic characteristics of generalized anxiety disorder and worry. Biol Psychiatry 1996;39:255-66.

56. Kim HG, Cheon EJ, Bai DS, Lee YH, Koo BH. Stress and heart rate variability: a meta-analysis and review of the literature. Psychiatry Investig 2018;15:235-45.

57. Indranada AM, Mullen SA, Wong MJ, D'Souza WJ, Kanaan RAA. Preictal autonomic dynamics in psychogenic nonepileptic seizures. Epilepsy Behav 2019;92:206-12.

58. Reinsberger C, Perez DL, Murphy MM, Dworetzky BA. Pre- and postictal, not ictal, heart rate distinguishes complex partial and psychogenic nonepileptic seizures. Epilepsy Behav 2012;23:68-70.

59. Lee MH, Smyser CD, Shimony JS. Resting-state fMRI: a review of methods and clinical applications. AJNR Am J Neuroradiol 2013;34:1866-72.

60. Ding JR, An D, Liao W, Li J, Wu GR, Xu Q, et al. Altered functional and structural connectivity networks in psychogenic non-epileptic seizures. PLoS One 2013;8:e63850.

61. Telesford QK, Joyce KE, Hayasaka S, Burdette JH, Laurienti PJ. The ubiquity of small-world networks. Brain Connect 2011;1:367-75.

62. van der Kruijs SJ, Bodde NM, Vaessen MJ, Lazeron RH, Vonck K, Boon P, et al. Functional connectivity of dissociation in patients with psychogenic non-epileptic seizures. J Neurol Neurosurg Psychiatry 2012;83:239-47.

63. van der Kruijs SJ, Jagannathan SR, Bodde NM, Besseling RM, Lazeron $\mathrm{RH}$, Vonck KE, et al. Resting-state networks and dissociation in psychogenic non-epileptic seizures. J Psychiatr Res 2014;54:126-33.

64. Li R, Liu K, Ma X, Li Z, Duan X, An D, et al. Altered functional connectivity patterns of the insular subregions in psychogenic non-epileptic seizures. Brain Topogr 2015;28:636-45.

65. Ding J, An D, Liao W, Wu G, Xu Q, Zhou D, et al. Abnormal functional connectivity density in psychogenic non-epileptic seizures. Epilepsy Res 2014;108:1184-94.

66. Dienstag A, Ben-Naim S, Gilad M, Ekstein D, Arzy S, Eitan R. Memory and motor control in patients with psychogenic non-epileptic seizures. Epilepsy Behav 2019;98:279-84.

67. Szaflarski JP, Allendorfer JB, Nenert R, LaFrance WC Jr, Barkan HI, DeWolfe J, et al. Facial emotion processing in patients with seizure disorders. Epilepsy Behav 2018;79:193-204.

68. Allendorfer JB, Nenert R, Hernando KA, DeWolfe JL, Pati S, Thomas AE, et al. FMRI response to acute psychological stress differentiates patients with psychogenic non-epileptic seizures from healthy controls - A biochemical and neuroimaging biomarker study. Neuroimage Clin 2019;24: 101967.

69. Zhang SW, Liu YX. Changes of serum adrenocorticotropic hormone and cortisol levels during sleep seizures. Neurosci Bull 2008;24:84-8.

70. Novakova B, Harris PR, Reuber M. Diurnal patterns and relationships between physiological and self-reported stress in patients with epilepsy and psychogenic non-epileptic seizures. Epilepsy Behav 2017;70:204-11.

71. van der Kruijs SJ, Vonck KE, Langereis GR, Feijs LM, Bodde NM, Lazeron $\mathrm{RH}$, et al. Autonomic nervous system functioning associated with psychogenic non-epileptic seizures: Analysis of heart rate variability. Epilepsy Behav 2016;54:14-9.

72. Li R, Li Y, An D, Gong Q, Zhou D, Chen H. Altered regional activity and inter-regional functional connectivity in psychogenic non-epileptic seizures. Sci Rep 2015;5:11635.

How to cite this article: Yeom JS, Bernard H, Koh S. Myths and truths about pediatric psychogenic nonepileptic seizures. Clin Exp Pediatr 2021;64:251-9. https://doi.org/10.3345/cep. 2020.00892 